ACTA MYCOLOGICA

Vol. 42 (2): 219-233

2007
Dedicated to Professor Alina Skirgietto

on the occasion of her ninety-fifth birthday

\title{
The occurrence of, and economic losses caused by Armillaria in the Western Carpathian Mts
}

\author{
${ }^{1}$ ADAM KALISZEWSKI, ${ }^{2}$ PAWEL LECH and ${ }^{2}$ TOMASZ OSZAKO
}

\author{
${ }^{1}$ Department of Forest Economics, Forest Research Institute \\ Sękocin Stary, Braci Leśnej 3, PL-05-090 Raszyn, A.Kaliszewski@ibles.waw.pl \\ ${ }^{2}$ Department of Forest Phytopathology, Forest Research Institute \\ Sękocin Stary, Braci Leśnej 3, PL-05-090 Raszyn
}

Kaliszewski A., Lech P., Oszako T.: The occurrence of, and economic losses caused by Armillaria in the Western Carpathian Mts. Acta Mycol. 42 (2): 219-233, 2007.

An investigation carried out in the Western Carpathian Mountains (Ujsoły, Węgierska Górka, Ustroń and Wisła Forest Districts) demonstrated a strong relationship between dieback in Norway spruce stands and the intensity of occurrence of Armillaria ostoyae. For the most endangered site types - mountain deciduous forest (LG) and mountain mixed forest (LMG), analyses of losses of annual volume increment and of stand productivity were performed, and their financial dimensions determined. The greatest losses - of about $8 \mathrm{~m}^{3} / \mathrm{ha} / \mathrm{year}$ for tree stands of the age of 100 years, and $400 \mathrm{~m}^{3} /$ ha for the rotation period - were found for LG (Mountain broadleaved forest) site type.

Key words: Armillaria occurrence, economic losses, spruce root rot, Carpathian Mountains

\section{INTRODUCTION}

Root rots caused by fungi of the genus Armillaria represent one of the most important problems for Polish forestry. The most serious losses due to them are to be noted in coniferous stands (Si e r ot a et al. 2003). According to data from the State Forests administration, damage due to Armillaria extended over a total of 144,000 ha in 1999, cf. more than 200,000 ha in 2003. Five species of the genus Armillaria have been recorded in Poland, namely $A$. borealis, A. gallica, A. ostoyae, A. cepistipes and A. mellea (Żółciak 1991, 1999a). While A. ostoyae, A. cepistipes and $A$. gallica are present across the country, $A$. borealis is a species of northern and central parts, and $A$. mellea is confined to just a small area near Gubin by the German border (Żółciak 2003).

A. ostoyae has been reported from coniferous, broadleaved and mixed stands, and in a wide range of forest habitats from fresh coniferous forest, through to moist broadleaved forest, alder-ash woodland and fertile broadleaved forest habitat in 
the mountains (LMG, LG, LLG) - including to an altitude of some $1100 \mathrm{~m}$ a.s.l. (Źółciak 1999b). However, its preference is for coniferous species, especially spruce, Scots pine and fir. In Poland $A$. ostoyae displays a decided dominance in managed forests. It has been noted on the greatest variety of shrubs and trees (23 species), including all the tree species native to Poland that form forests, i.e. Scots pine, Norway spruce, fir, oaks, beech and birch (Żółciak 2003).

In the pine stands of the Polish lowlands, and most notably in the spruce forests of the Western Carpathians, Armillaria root rot is present as an epiphytosis (Ca pe cki 1994, 1997; Lech 2003). Furthermore, recent years have seen it appear in stands that had been considered resistant - in the beech forests of the Bieszczady Mountains and Pomerania, as well as on oaks throughout the country (Źółciak 1999b; Łakomy, Siwe cki 2000). It may thus serve a useful indicator of the state of health of a forest, inter alia on account of the constancy of colonisation of the substratum (tree boles and roots), as well as the length of the disease process. Its presence depicts areas with a greater predisposition to other stress and injurious factors, being an indicator of the pathological state of the stand, as well as pointing to changes of an ecosystemic nature. It not only does economic damage, but also brings about changes in the functioning of a biocoenosis, leading to degradation of stands, a reduction in the productivity of the habitat, and even deforestation. This impact has been registered in the spiral disease model (Manion 1981), wherein it features as a predisposing factor, an initiating factor and a factor co-participating in the treedieback process.

Research has not so far been carried out in Poland with a view to discovering the level of the damage sustained by forestry through the reduced productivity of stands colonized by pathogenic fungi. As a consequence of the harmful impact of fungi from the economic point of view, damage is done to single trees and to whole groups of them, a possible result being the dieoff of whole patches of forest, necessitating premature felling. The consequent loss of growing stock may play a major role in limiting the productive potential of forest habitats.

The means of calculating losses due to damage arising in forests are as set out in the Agricultural and Forest Land Protection Act 1995 (Ustawa 1995). The level of one-off compensation for the premature felling of a stand is set as the difference between the expected value of the stand at rotation age, as detailed in the forest management plan, simplified forest management plan or forest inventory, and the value at the moment of felling (Podgórski et al. 2001). The principles for the valuation of stands and level of damage in the case of their premature felling are in turn laid down in the 2002 Regulation of the Minister of the Environment on one-off damages for the premature felling of a stand (Rozporządzenie 2002).

The work presented here had as its aim the determination of the environmental conditioning behind the occurrence of Armillaria root rot in stands of the Western Carpathians. In addition, the work sought to determine the size of losses as expressed in terms of reduced stand volume increment, and the current value of lost timber expressed per hectare and per year. In this, no account was taken of the losses resulting from the impact on growth of other stress factors like insect pests, air pollution and weather anomalies (droughts). Within Poland, the western part of the Carpathians encompasses the chain of mountains comprising the Beskid Śląski, Żywiecki, Mały, Wyspowy and Sądecki ranges, as well as the Gorce and Tatra Mountains. The 
forests in this region are dominated by spruce, whose average volume share in the stand structure at present exceeds $62 \%$ (S zabla 2003), locally even attaining 95\% (Capecki 1994). The shares taken by other species are thus markedly lower - on average beech accounts for $19 \%$ of volume, Scots pine and fir for $6 \%$ each, oak for $3 \%$, birch for $2 \%$ and other species also for $2 \%$. Average annual increment in these stands exceeds $4.5 \mathrm{~m}^{3} /$ ha (Szabla 2003).

Forests in this western part of the Carpathians are subject to the impact of many biotic, abiotic and anthropogenic stress factors, including primary and secondary insect pests (most especially bark beetles), infectious fungal diseases (first and foremost those giving rise to root rot), weather anomalies (drought, wind and snow), and air pollution (Zwoliński 2003). Root pathogens are of particular significance in this area - fungi of the genus Armillaria (mainly A. ostoyae), and Heterobasidion annosum, which occurs more frequently here than anywhere else in Poland's forests (Lech 2003).

\section{MATERIAL AND METHODS}

The area chosen for study was the Ujsoła Forest District, located in the boundary zone between the Beskid Żywiecki and Beskid Śląski ranges and typical of the region in terms of its stand structure and the threats posed to it. It is characterised by a high (and in recent years increasing) level of damage posed to stands by Armillaria root rot, as well as by differences in the degree of damage from place to place. This fact made possible the establishment in 2001 and 2002, within the District (and specifically its Ujsoła sub-district), of a total of 26 2-are observation plots so selected as to take account of both the differences in the level of threat and different stand and habitat parameters (altitude above sea level and the stand structure in terms of age and species). The plots were arranged in groups of between 3 and 10 along 4 transects $700 \mathrm{~m}$ to $4 \mathrm{~km}$ long. These were found in uniform spruce forest and mixed stands (spruce-beech or spruce-beech-fir), in high-mountain coniferous forest habitat (BWG), mountain mixed coniferous forest (BMG), mountain mixed broadleaved forest (LMG) and mountain broadleaved forest (LG), at altitudes of between c. 600 and c. $1350 \mathrm{~m}$ a.s.1. Observation plots were subjected to assessments of the occurrence of Armillaria, including that on dead stumps as well on trees. The results of this assessment were compiled, together with information on the volume of deadwood removed in the years 1987-2001, by reference to stand areas in which observation plots were located (use was made of volume expressed per year and per hectare). They were then the subject of analysis of variance taking account of forest type and stand species structure as sources of variability.

Also the potential economic losses incurred as a result of the lowering of stand values on account of root-rot attacks were assessed. Estimation of damage was done for spruce stands, i.e. those most threatened by Armillaria and also prevalent in the Western Carpathians, occurring on the two habitat types LG and LMG. The small number of plots in the BMG and BWG habitats did not allow for any analysis in these forest habitats. Calculations also made use of data on the amount of deadwood generated in the years 1985-2001.

In determining the value of the damage, use was made of the formula below [1], this being a modification of that proposed in the Regulation of the 
Minister of the Environment on one-off compensation for premature felling of a stand (Rozporządzenie 2002). This formula serves in detailing losses due to the reduced volume increment resulting from the partial damage to the stand (Zajac et al. 1998). The formula is as follows:

$$
\mathrm{S}=(\mathrm{Wu}-\mathrm{Wi}) \times(\mathrm{Zi}-\mathrm{Zs}) \times \mathrm{P}
$$

Where:

$S$ is the loss due to the reduction in increment caused by the partial damaging of the stand; $W u$ is the expected value of 1 ha of standing trees in a stand, in line with the expenditure necessary for its development to age $u$; Wi is the expected value of 1 ha of standing trees in a stand in line with the expenditure necessary for its development to age $i ; u$ is the rotation age of the stand subject to estimation; $Z i$ is the stock density prior to the damage; $i$ is the current age of the stand; $Z s$ is the expected stock density of the stand following the thinning out of damaged trees, $P$ is the area of the stand in ha.

The index of expected stand value allows for a determination of the value of a stand during each year of its existence (from establishment of the plantation to felling at the rotation age). The method rests on the assumption that the whole period of life of the stand includes only two times at which direct estimates of its value can be made, i.e. 1) the age of establishment of the plantation $(i=1)$, at which time the value equals the cost of establishment, and 2) the rotation age $u(i=u)$, at which time the value is given by the combined value of the harvested wood assortments. The value of a stand at age $i(W i)$ is calculated by reducing its value at the rotation age using a coefficient that differs in line with stand age (Partyka, Parzuchowska 1993; Parzuchowska et al. 1997; Zajac et al. 1998).

Indices of expected values of stands at ages $i$ and $u$ (with account being taken of species and stand quality classes) are set out in the tables of stand value indices constituting an annex to the aforementioned Regulation. These tables contain values in conversion units, i.e. ones expressed in $\mathrm{m}^{3}$ of raw timber. The values obtained from the valuation, expressed in terms of conversion units, are multiplied by the average wood selling price published annually by the Central Statistical Office for the purposes of calculation of the forest tax.

The assessment of the expected (potential) value of losses is made in three stages:

1. determination of the potential loss in the capacity to generate stand increment,

2. estimation of the potential decline in stock density of stands colonized by Armillaria,

3. estimation of the potential economic losses in the stand as Armillaria-induced disease progresses.

The starting point for completion of the first stage of the research was provided by data on the mean annual volume removed in the period 1985-1997 through the clearing of deadwood from variously-aged spruce stands or stands with a considerable share of spruce. Information on stands in the LG habitat was available for 16 research plots taking in stands aged 6 to 100 years. In the case of stands of the LMG habitat, the information came from 5 plots established in stands of ages 75 to 125 (Tab. 1). 
Table 1

Characteristics of the observation plots located within Ujsola Forest District

\begin{tabular}{|c|c|c|c|c|c|c|c|}
\hline No. & $\begin{array}{c}\text { Forest } \\
\text { habitat }\end{array}$ & $\begin{array}{c}\text { Stand } \\
\text { structure }\end{array}$ & $\begin{array}{l}\text { No. of } \\
\text { trees }\end{array}$ & $\begin{array}{c}\text { No. of } \\
\text { stumps }\end{array}$ & $\begin{array}{c}\text { No. of } \\
\text { Armillaria }\end{array}$ & $\begin{array}{l}\text { Altitude } \\
\text { a.s.l. }\end{array}$ & $\begin{array}{l}\text { Volume of } \\
\text { deadwood }\end{array}$ \\
\hline & type & & & & & $\mathrm{m}$ & $\mathrm{m}^{3} / \mathrm{ha} / \mathrm{yr}$ \\
\hline 1 & LG & $\mathrm{S}$ & 40 & 26 & 0 & 1040 & 4.85 \\
\hline 2 & LG & $\mathrm{S}$ & 35 & 0 & 1 & 1010 & 2.80 \\
\hline 3 & LG & $\mathrm{S}$ & 5 & 5 & 3 & 785 & 2.16 \\
\hline 4 & LG & $\mathrm{S}$ & 18 & 5 & 2 & 780 & 2.19 \\
\hline 5 & LG & $\mathrm{S}$ & 23 & 12 & 7 & 750 & 13.09 \\
\hline 6 & LG & $\mathrm{S}$ & 9 & 5 & 5 & 750 & 1.19 \\
\hline 7 & LG & $\mathrm{S}$ & 10 & 12 & 9 & 720 & 9.88 \\
\hline 8 & LG & $\mathrm{S}$ & 21 & 14 & 8 & 650 & 11.58 \\
\hline 9 & LG & $\mathrm{M}$ & 17 & 5 & 4 & 980 & 6.70 \\
\hline 10 & LG & M & 28 & 9 & 6 & 970 & 8.00 \\
\hline 11 & LG & $\mathrm{M}$ & 20 & 7 & 5 & 900 & 8.58 \\
\hline 12 & LG & $\mathrm{M}$ & plantation & 5 & 5 & 846 & 1.19 \\
\hline 13 & LG & M & 30 & 12 & 6 & 810 & 9.14 \\
\hline 14 & LG & M & 33 & 13 & 7 & 770 & 2.79 \\
\hline 15 & $\overline{\mathrm{LG}}$ & $\mathrm{M}$ & $\begin{array}{l}\text { young } \\
\text { plant. }\end{array}$ & No data & No data & 758 & 9.58 \\
\hline 16 & $\overline{L G}$ & $\mathrm{M}$ & plantation & 2 & 2 & 660 & 19.59 \\
\hline 17 & $\overline{\mathrm{LMG}}$ & $\mathrm{S}$ & 11 & 8 & 6 & 990 & 0.57 \\
\hline 18 & LMG & $\mathrm{S}$ & 11 & 7 & 3 & 1030 & 0.29 \\
\hline 19 & LMG & $\mathrm{S}$ & 14 & 6 & 2 & 1055 & 1.26 \\
\hline 20 & LMG & $\mathrm{S}$ & 19 & 28 & 6 & 1100 & 0.00 \\
\hline 21 & LMG & $\mathrm{M}$ & 14 & 10 & 6 & 850 & 0.00 \\
\hline 22 & LMG & $\mathrm{M}$ & 11 & $\frac{1}{4}$ & 2 & 950 & 1.19 \\
\hline 23 & BMG & $\mathrm{S}$ & 13 & 17 & 1 & 1140 & 1.26 \\
\hline 24 & BWS & $\mathrm{S}$ & 18 & 7 & 0 & 1320 & 0.00 \\
\hline 25 & BWG & $\mathrm{S}$ & 17 & 28 & 0 & 1285 & 0.00 \\
\hline 26 & BWG & $\mathrm{S}$ & 34 & 52 & 0 & 1255 & 0.22 \\
\hline
\end{tabular}

The above data allowed for the determination of relationships between the mean volume of deadwood being thinned out of spruce stands annually and the ages of those stands. These relationships are presented in Figure 1.

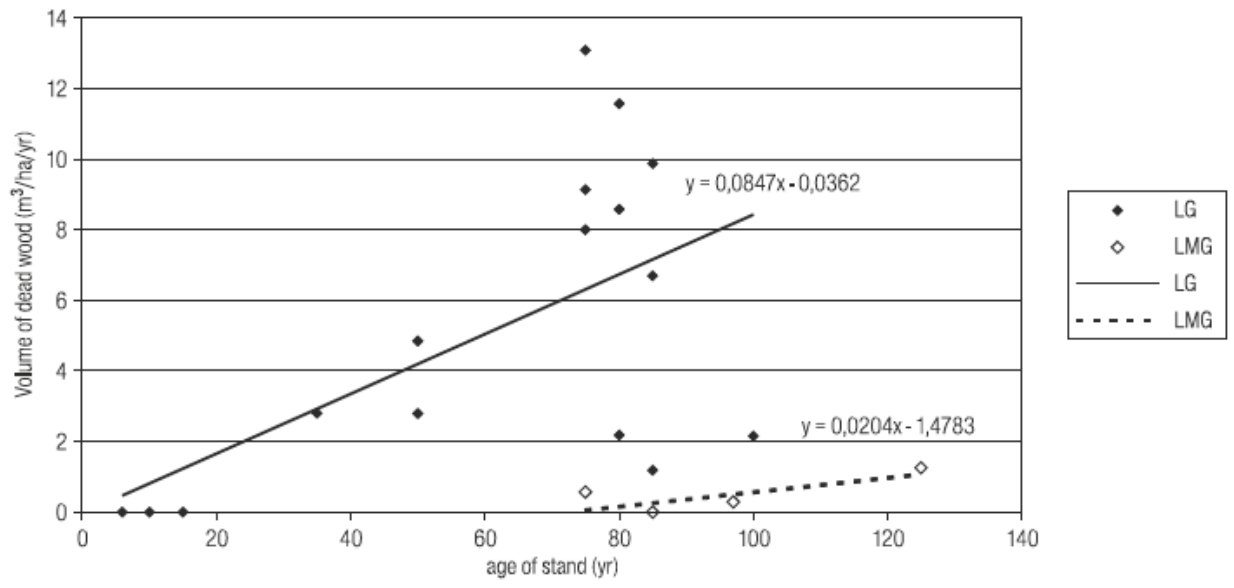

Fig. 1. Mean annual volume of deadwood in spruce stands or those in which spruce is prevalent in the habitats of mountain broadleaved forest (LG) and mountain mixed broadleaved forest (LMG). 
The functional relationships obtained made it possible to determine potential losses in terms of stand increment. The potential increment of spruce stands was established on the basis of the tables of stand yield and increment (Szymkiewicz 2001), accepting that the further calculations would make use of data for current increment of wood with diameter of at least $7 \mathrm{~cm}$ overbark, with a stock density equal to 1.0. It was assumed that stands of habitat LG were of quality class I, while those of habitat LMG were of class II (Tr a m ple r 1990). Losses to stand increment were defined as the difference between their potential current increment overbark and the volume of deadwood removed. The results were presented in absolute terms (in $\mathrm{m}^{3} / \mathrm{ha} / \mathrm{year}$ ), as well as relatively - by reference to the percentage reduction in potential increment (Tabs 2 and 3 ).

The second stage involved determination of the scale of the reduction in the potential stock density of those stands subject to the unfavourable impact of Armillaria fungi. To this end, tables of stand yield and increment (Szymkiewicz 2001) were used to determine the reduction in the total productivity overbark of stands, as well as - for comparison - the growing stock.

The use of total productivity overbark in this case proceeds from an assumption that the process of dieback takes in, not only those trees potentially capable of surviving through to the rotation age (i.e. the main stand), but also those that would be harvested through pre-final felling (i.e. the subordinate stand). It was thereby assumed that data on the quantities of deadwood being removed encompassed both information on the volume of trees that would have been removed by thinning irrespective of the presence or absence of disease, and those that would have formed the mature stand were disease not present. Comparison of the volume of deadwood removed throughout the life of the stand with data on total potential productivity overbark in a stand not attacked by disease supplies reliable information as to the theoretical reduction in stock density.

Table 2

Potential losses of increment in spruce stands of the LG habitat

\begin{tabular}{|c|c|c|c|c|}
\hline $\begin{array}{c}\text { Age } \\
(\mathrm{y})\end{array}$ & $\begin{array}{c}\text { Potential losses of } \\
\text { increment overbark } \\
\left(\mathrm{m}^{3} / \mathrm{ha} / \mathrm{yr}\right)\end{array}$ & $\begin{array}{c}\text { Potential current } \\
\text { annual increment } \\
\text { overbark } \\
\left(\mathrm{m}^{3} / \mathrm{ha} / \mathrm{yr}\right)\end{array}$ & $\begin{array}{c}\text { Reduced increment } \\
\text { overbark } \\
\left(\mathrm{m}^{3} / \mathrm{ha} / \mathrm{yr}\right)\end{array}$ & $\begin{array}{c}\text { Reduction in } \\
\text { potential increment } \\
\text { overbark }(\%)\end{array}$ \\
\hline 25 & 2.1 & 9.5 & 7.4 & 22 \\
\hline 30 & 2.5 & 13.3 & 10.8 & 19 \\
\hline 35 & 2.9 & 16.5 & 13.6 & 18 \\
\hline 40 & 3.4 & 18.7 & 15.3 & 18 \\
\hline 45 & 3.8 & 20.4 & 16.6 & 20 \\
\hline 50 & 4.2 & 21.0 & 16.8 & 23 \\
\hline 55 & 4.6 & 20.5 & 15.9 & 26 \\
\hline 60 & 5.0 & 19.5 & 14.5 & 30 \\
\hline 65 & 5.5 & 18.5 & 13.0 & 34 \\
\hline 70 & 5.9 & 17.5 & 11.6 & 43 \\
\hline 75 & 6.3 & 16.6 & 10.3 & 48 \\
\hline 80 & 6.7 & 15.8 & 9.1 & 53 \\
\hline 85 & 7.2 & 15.0 & 7.8 & 59 \\
\hline 90 & 7.6 & 14.2 & 6.6 & 66 \\
\hline 95 & 8.0 & 13.6 & 5.6 & \\
\hline 100 & 8.4 & 12.8 & 4.4 & \\
\hline
\end{tabular}


Table 3

Potential losses of increment in spruce stands of the LMG habitat

\begin{tabular}{|c|c|c|c|c|}
\hline $\begin{array}{c}\text { Age } \\
(\mathrm{y})\end{array}$ & $\begin{array}{c}\text { Potential losses of } \\
\text { increment overbark } \\
\left(\mathrm{m}^{3} / \mathrm{ha} / \mathrm{yr}\right)\end{array}$ & $\begin{array}{c}\text { Potential current } \\
\text { annual increment } \\
\text { overbark } \\
\left(\mathrm{m}^{3} / \mathrm{ha} / \mathrm{yr}\right)\end{array}$ & $\begin{array}{c}\text { Reduced increment } \\
\text { overbark } \\
\left(\mathrm{m}^{3} / \mathrm{ha} / \mathrm{yr}\right)\end{array}$ & $\begin{array}{c}\text { \% reduction in } \\
\text { potential increment } \\
\text { overbark }\end{array}$ \\
\hline 30 & & 8.8 & 8.8 & 0 \\
\hline 35 & & 11.7 & 11.7 & 0 \\
\hline 40 & & 14.1 & 14.1 & 0 \\
\hline 45 & & 15.8 & 15.8 & 0 \\
\hline 50 & & 16.9 & 16.9 & 0 \\
\hline 55 & & 17.1 & 17.1 & 0 \\
\hline 60 & & 16.7 & 16.7 & 0 \\
\hline 65 & & 15.8 & 15.8 & 0 \\
\hline 70 & & 15.0 & 15.0 & 1 \\
\hline 75 & 0.1 & 14.3 & 14.2 & 2 \\
\hline 80 & 0.2 & 13.6 & 13.4 & 3 \\
\hline 85 & 0.3 & 12.8 & 12.5 & 4 \\
\hline 90 & 0.4 & 12.1 & 11.7 & 5 \\
\hline 95 & 0.5 & 11.6 & 11.1 & 0 \\
\hline 100 & 0.6 & 10.6 & 10.0 & \\
\hline
\end{tabular}

Table 4

Potential losses of total productivity overbark in spruce stands of the LG habitat

\begin{tabular}{|c|c|c|c|c|c|c|c|}
\hline $\begin{array}{c}\text { Age } \\
(\mathrm{y})\end{array}$ & $\begin{array}{c}\text { Size of } \\
\text { losses } \\
\text { overbark } \\
\left(\mathrm{m}^{3} / \mathrm{ha}\right)\end{array}$ & $\begin{array}{c}\text { Growing } \\
\text { stock } \\
\left(\mathrm{m}^{3} / \mathrm{ha}\right)\end{array}$ & $\begin{array}{c}\text { Total pro- } \\
\text { ductivity } \\
\text { overbark } \\
\left(\mathrm{m}^{3} / \mathrm{ha}\right)\end{array}$ & $\begin{array}{c}\text { Reduced } \\
\text { volume } \\
\text { overbark } \\
\left(\mathrm{m}^{3} / \mathrm{ha}\right)\end{array}$ & $\begin{array}{c}\text { Level of } \\
\text { loss in } \\
\text { volume } \\
\text { overbark } \\
(\%)\end{array}$ & $\begin{array}{c}\text { Reduced } \\
\text { total pro- } \\
\text { ductivity } \\
\text { overbark } \\
\left(\mathrm{m}^{3} / \text { ha }\right)\end{array}$ & $\begin{array}{c}\text { Size of } \\
\text { losses to } \\
\text { total pro- } \\
\text { ductivity } \\
\text { overbark } \\
(\%)\end{array}$ \\
\hline 25 & 2 & 70 & 71 & 68 & 3 & 69 & 3 \\
\hline 30 & 14 & 125 & 134 & 111 & 11 & 120 & 10 \\
\hline 35 & 28 & 189 & 212 & 161 & 15 & 184 & 13 \\
\hline 40 & 43 & 262 & 305 & 219 & 17 & 262 & 14 \\
\hline 45 & 61 & 338 & 407 & 277 & 18 & 346 & 15 \\
\hline 50 & 82 & 410 & 510 & 328 & 20 & 428 & 16 \\
\hline 55 & 104 & 475 & 611 & 371 & 22 & 507 & 17 \\
\hline 60 & 128 & 530 & 707 & 402 & 24 & 579 & 18 \\
\hline 65 & 155 & 574 & 797 & 419 & 27 & 642 & 19 \\
\hline 70 & 183 & 610 & 883 & 427 & 30 & 700 & 21 \\
\hline 75 & 214 & 640 & 966 & 426 & 33 & 752 & 22 \\
\hline 80 & 247 & 666 & 1047 & 419 & 37 & 800 & 24 \\
\hline 85 & 282 & 689 & 1126 & 407 & 41 & 844 & 25 \\
\hline 90 & 319 & 708 & 1200 & 389 & 45 & 881 & 27 \\
\hline 95 & 358 & 723 & 1269 & 365 & 50 & 911 & 28 \\
\hline 100 & 400 & 734 & 1333 & 334 & 54 & 933 & 30 \\
\hline & & & & & & & \\
\hline
\end{tabular}


A. Kaliszewski et al.

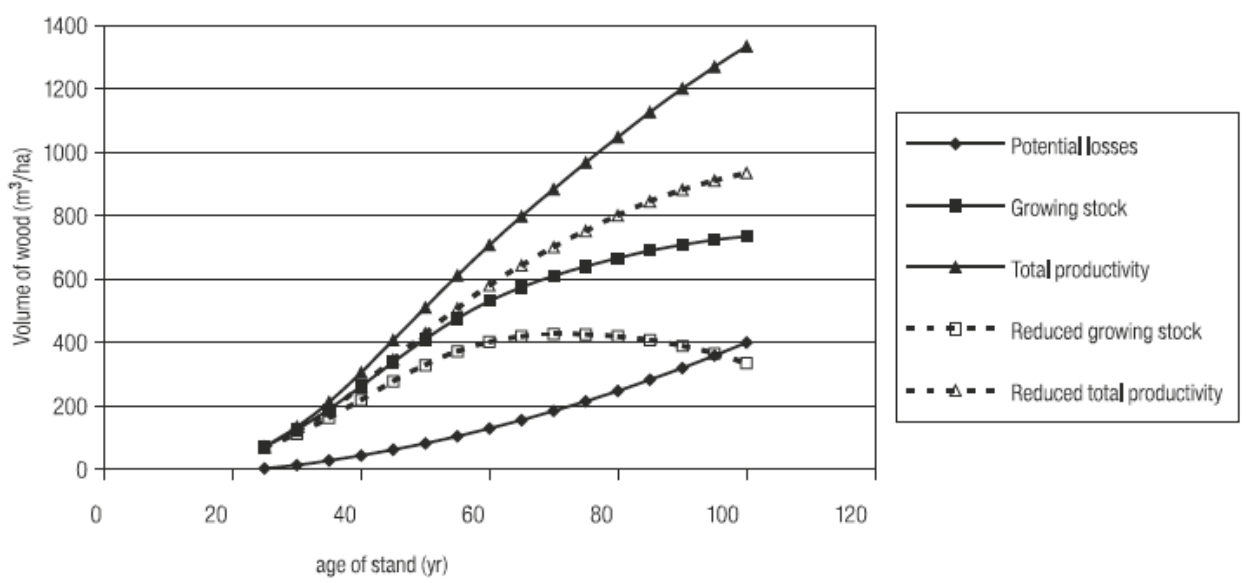

Fig. 2. Losses in spruce stand productivity in the LG habitat.

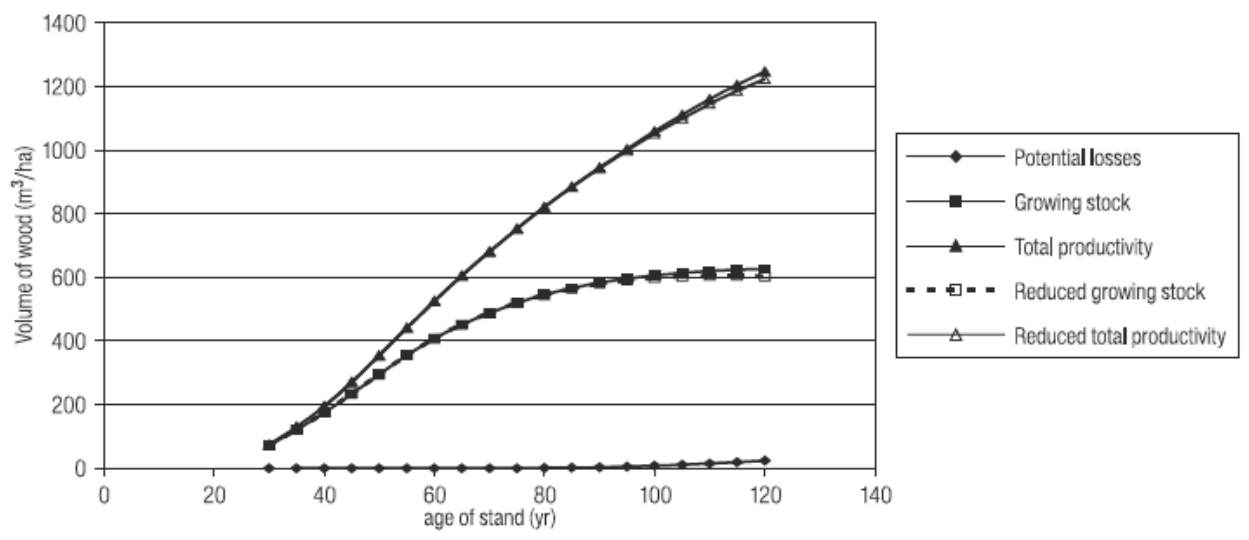

Fig. 3. Losses in spruce stand productivity in the LMG habitat.

The results obtained were presented in absolute terms $\left(\mathrm{m}^{3} / \mathrm{ha}\right)$, as well as as relative values - as a percentage reduction of the total productivity overbark and the growing stock (Tabs 4 and 5; Figs 2 and 3). The level of the losses to total productivity overbark (in percentage terms) determines the extent to which the stock density is reduced as a result of the thinning out of trees afflicted by Armillaria root rot.

The final stage of the research entailed the determination of potential economic losses in stands with developing Armillaria-induced disease. To this end, use was made of tables of stand value indices (Rozporządzenie 2002), as well as the formula discussed above [1]. The value for potential losses so obtained, as expressed in conversion units ( $\mathrm{m}^{3}$ of wood) was multiplied by the average selling price - of $107.7 \mathrm{zt} /$ $\mathrm{m}^{3}$ in 2003 (Komunikat 2003).

The MS Office 2000 (Access, Excel, Word), Statgraphics Plus for Windows and ArcView GIS v. 3.0 computer programmes were used in carrying out the analyses, tabulations and graphic presentations contained in the present study. 


\section{RESULTS}

The assessment of the occurrence of Armillaria points to a marked concentration in plots located on the fertile habitats, i.e. LMG and especially LG. The numbers of stumps colonised by $A$. ostoyae (only this species was identified) and of trees infected by the pathogen amounted to 242 and 208 in the LG and LMG habitats respectively, when expressed per ha of stand. On plots in the poorer habitats - BMG and BWG and at altitudes of more than $1100 \mathrm{~m}$ a.s.1., Armillaria was noted from only $1 \mathrm{stump}$ (Tab.1). These habitats are also characterised by a low volume of deadwood (reaching $1.26 \mathrm{~m}^{3} / \mathrm{ha}$ /year, while the figure for the LG habitat may be as high as $19.59 \mathrm{~m}^{3} /$ ha/year. Analysis of variance pointed to the statistical significance of differences in the frequency of occurrence of Armillaria (as expressed by the ratio of the number of Armillaria-affected stumps and trees to the total number of both present on the observation plot, in the case of the fertile habitats (LG and LMG) and the poor ones (of coniferous forest - BMG and BWG). The differences between broadleaved-forest-type habitats did not achieve statistical significance, however (Fig. 4). The analysis of variance also allowed significant differences in the volume of deadwood produced by the forest habitat types to be noted (Fig. 5). However, in this case it was the mountain broadleaved forest habitat (LG) that had a significantly greater amount of deadwood. The differences between coniferous forest habitats and the mountain mixed broadleaved forest (LMG) did not attain statistical significance.

However, the analyses carried out didn't statistically-significant differences in the occurrence of Armillaria and the volume of deadwood, in the case of the plots located in either spruce stands or mixed stands (Figs 6 and 7 respectively). This would seem to be the result of the large (over-50\%) share taken by spruce where the species structure of the mixed stands is concerned (there is over $75 \%$ dominance of this species as regards the quantitative structure of stumps).

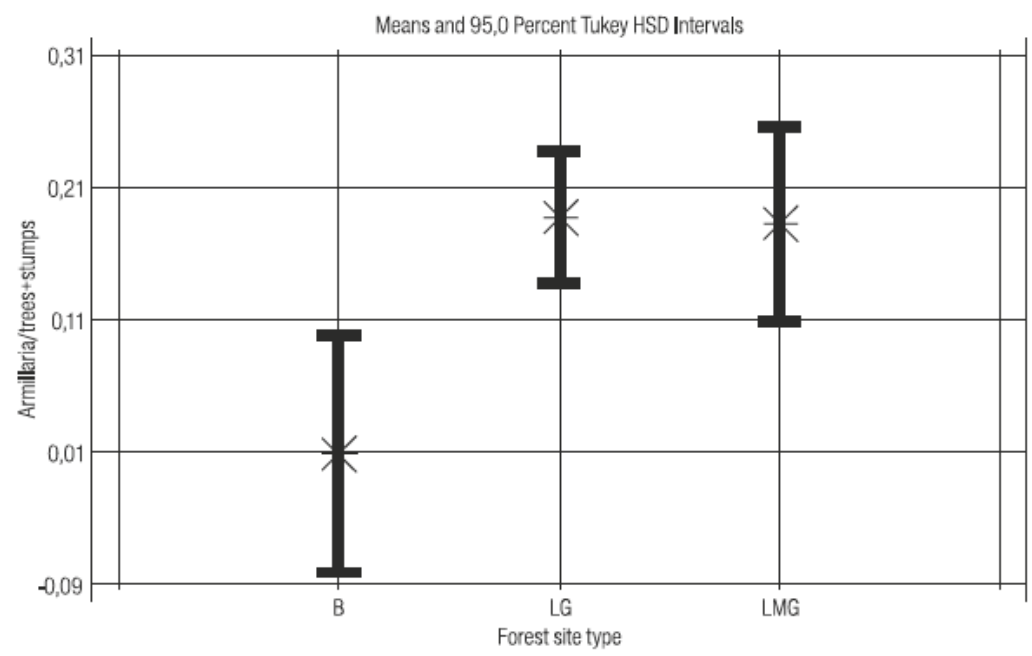

Fig. 4. Index for the colonisation of trees and stumps by Armillaria on the observation plots located in the coniferous forest habitat B, the mountain broadleaved forest LG and the montain mixed broadleaved forest LMG. 
A. Kaliszewski et al.

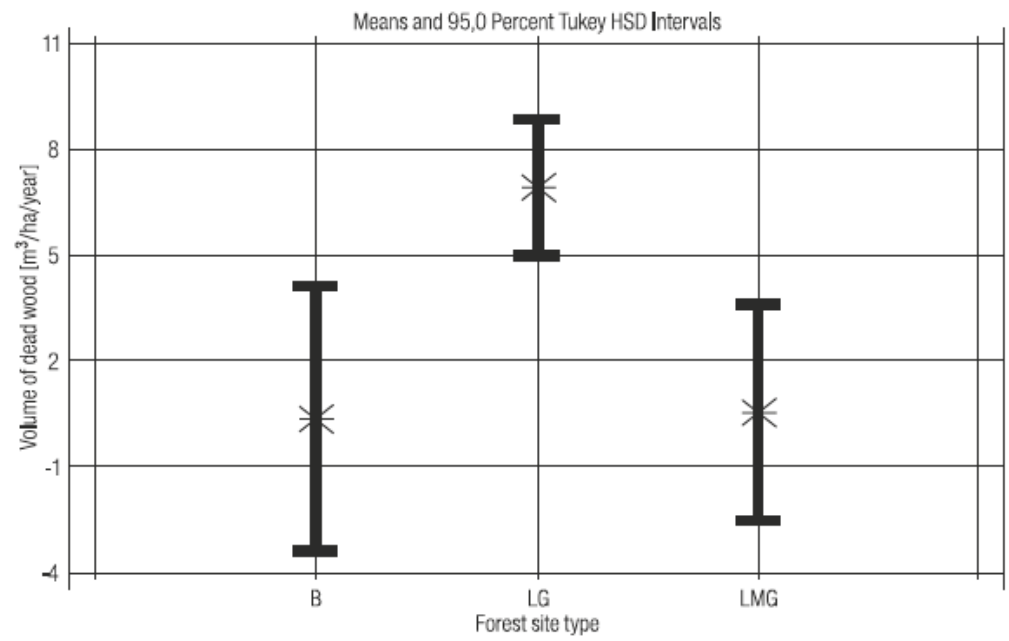

Fig. 5. Volume of deadwood on observation plots located in the coniferous forest habitat (B), the mountain broadleaved forest habitat $(L G)$ and the mountain mixed broadleaved habitat (LMG).

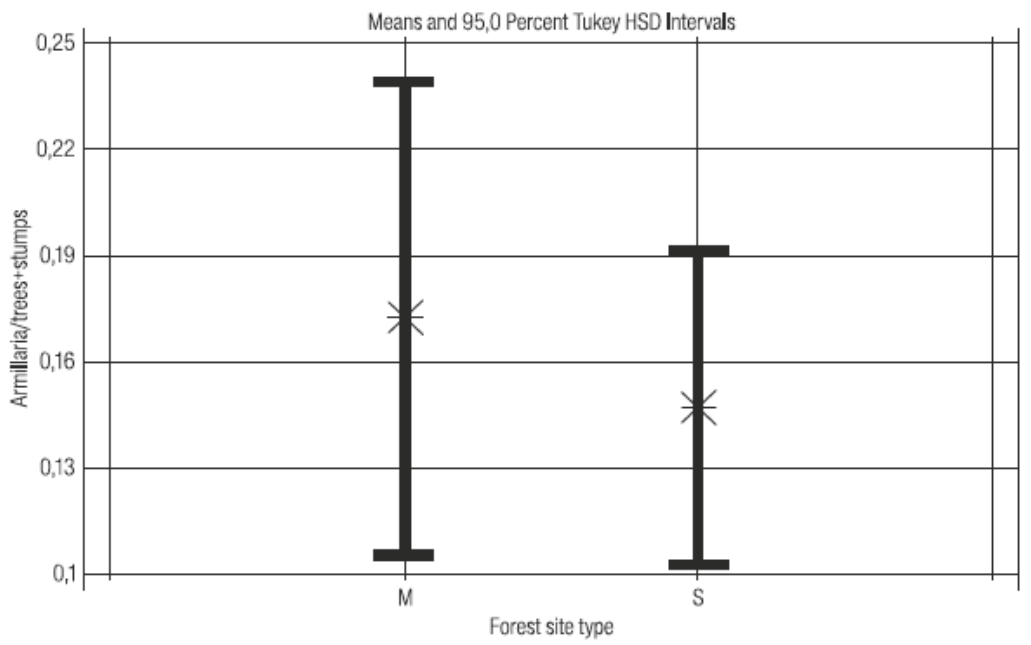

Fig. 6. Index for the colonisation of trees and stumps by Armillaria on observation plots in unfiorm spruce forest (S) and mixed stands (M).

The relationship between the mean volume of deadwood thinned out annually from spruce stands and the ages of these stands is as presented in Fig. 1. In relation to the type of habitat, this function can be described by the following formulae:

$\mathrm{y}=0.0847 \mathrm{x}-0.0362$

in the case of the spruce stands in the LG habitat (quality class I), and $\mathrm{y}=0.0204 \mathrm{x}-1.4783$

for spruce stands in the LMG habitat (quality class II), where $x$ denotes the age of the stand. 


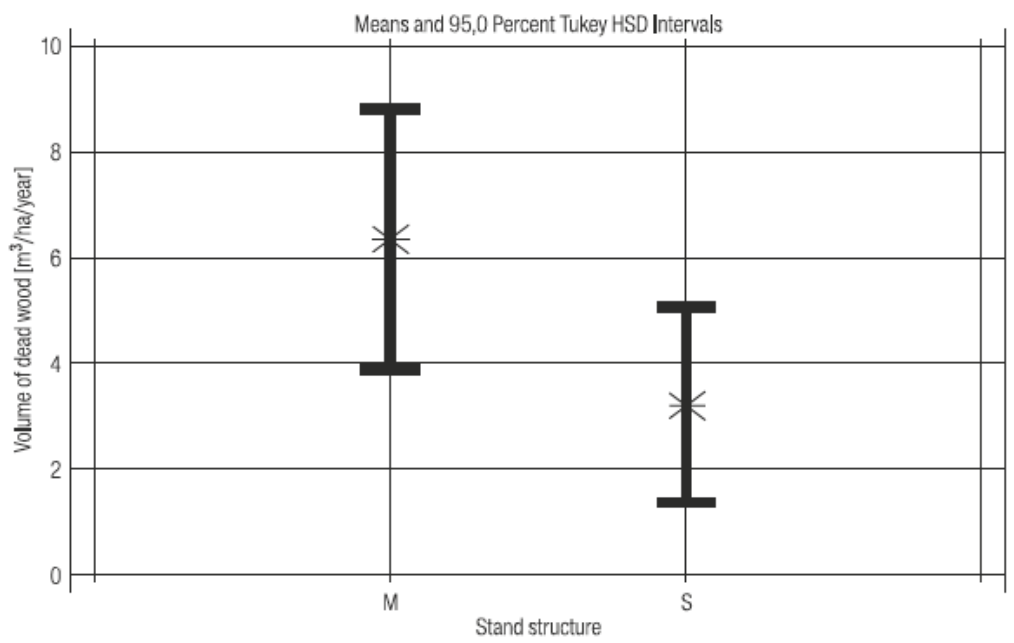

Fig. 7. Volume of deadwood on observation plots located in uniform spruce forest (S) and mixed stands (M).

The above formulae were introduced on the basis of empirical data on the amounts of deadwood being removed from selected plots within Ujsoła Forest District. The straight-line relationship shows that an intensification of the phenomenon of tree-mortality is associated with increasing stand age and may be of particular significance in mature stands where the current increment is ever smaller. In this way the relative losses in the volume of stands of the older age classes are greater than is the case for the younger classes. As the presented figure (Fig. 1) makes clear, this phenomenon is only of economic significance in the LG habitat. In the case of LMG, the losses are limited and of practically no economic significance.

The calculations of loss of stand volume confirm the aforementioned relationship. A cessation of efforts to combat disease in the LG habitat leads to a loss of $30 \%$ of the total productivity overbark in a 100-year-old stand, while the figure is $38 \%$ in a 120-year-old stand (for comparison, this is a volume greater than half of that at rotation age). In the LMG habitat, the losses are inconsiderable, not exceeding $2 \%$ of the total productivity overbark (cf. Tabs 4 and 5 and Figs 2 and 3).

Results regarding the size of potential losses - should efforts to combat Armillaria cease - are presented for different sub-classes in Table 6, as well as graphically in Fig. 8. The course taken by the curve for the level of loss in stands of the LG habitat points to a dramatic increase in the case of 20-40 year-old stands, followed by a steady fall to the point where a value of zero is arrived at at the rotation age for the stand, albeit with potential losses being greater where a longer rotation period is adopted for a stand. Such a course to a curve reflects the method adopted in determining indices from tables of stand values: in the case of young stands, the indices are determined using the method of expenditure incurred, and hence the total costs borne in establishing and tending the young stands. In contrast, the measure for older stands bases itself around the expected value of the stand of rotation age. The lowering of the level of loss reflects the fact that a stand contains assortments that can be processed and sold, while there is also a reduction in the interval between the 
Table 5

Potential losses of total, productivity overbark in spruce stands of the LMG habitat

\begin{tabular}{|c|c|c|c|c|c|c|c|}
\hline $\begin{array}{c}\text { Age } \\
(\mathrm{y})\end{array}$ & $\begin{array}{c}\text { Size of } \\
\text { losses } \\
\text { overbark } \\
\left(\mathrm{m}^{3} / \mathrm{ha}\right)\end{array}$ & $\begin{array}{c}\text { Growing } \\
\text { stock } \\
\left(\mathrm{m}^{3} / \mathrm{ha}\right)\end{array}$ & $\begin{array}{c}\text { Total pro- } \\
\text { ductivity } \\
\text { overbark } \\
\left(\mathrm{m}^{3} / \text { ha }\right)\end{array}$ & $\begin{array}{c}\text { Reduced } \\
\text { volume } \\
\text { overbark } \\
\left(\mathrm{m}^{3} / \text { ha }\right)\end{array}$ & $\begin{array}{c}\text { Level of } \\
\text { loss in } \\
\text { volume } \\
\text { overbark } \\
(\%)\end{array}$ & $\begin{array}{c}\text { Reduced } \\
\text { total pro- } \\
\text { ductivity } \\
\text { overbark } \\
\left(\mathrm{m}^{3} / \mathrm{ha}\right)\end{array}$ & $\begin{array}{c}\text { Size of } \\
\text { losses to } \\
\text { total pro- } \\
\text { ductivity } \\
\text { overbark } \\
(\%)\end{array}$ \\
\hline 30 & 0 & 71 & 74 & 71 & 0 & 74 & 0 \\
\hline 35 & 0 & 121 & 130 & 121 & 0 & 130 & 0 \\
\hline 40 & 0 & 175 & 195 & 175 & 0 & 195 & 0 \\
\hline 45 & 0 & 234 & 271 & 234 & 0 & 271 & 0 \\
\hline 50 & 0 & 295 & 354 & 295 & 0 & 354 & 0 \\
\hline 55 & 0 & 355 & 441 & 355 & 0 & 441 & 0 \\
\hline 60 & 0 & 407 & 525 & 407 & 0 & 525 & 0 \\
\hline 65 & 0 & 451 & 605 & 451 & 0 & 605 & 0 \\
\hline 70 & 0 & 488 & 681 & 488 & 0 & 681 & 0 \\
\hline 75 & 0 & 519 & 753 & 519 & 0 & 753 & 0 \\
\hline 80 & 1 & 545 & 821 & 544 & 0 & 820 & 0 \\
\hline 85 & 2 & 566 & 885 & 564 & 0 & 883 & 0 \\
\hline 90 & 3 & 583 & 946 & 580 & 1 & 943 & 0 \\
\hline 95 & 5 & 596 & 1004 & 591 & 1 & 999 & 1 \\
\hline 100 & 8 & 606 & 1059 & 598 & 1 & 1051 & 1 \\
\hline 105 & 11 & 614 & 1111 & 603 & 2 & 1100 & 1 \\
\hline 110 & 15 & 620 & 1160 & 605 & 2 & 1145 & 1 \\
\hline 115 & 19 & 624 & 1205 & 605 & 3 & 1186 & 2 \\
\hline 120 & 23 & 627 & 1247 & 604 & 4 & 1224 & 2 \\
\hline
\end{tabular}

Table 6

Level of potential loss of value in spruce stands of the LG habitat with rotation ages of up to 100 years

\begin{tabular}{|c|c|c|c|c|c|c|c|c|c|c|}
\hline $\begin{array}{c}\text { Age } \\
\text { sub- } \\
\text { class }\end{array}$ & $\begin{array}{c}\text { Age } \\
\text { (yr) }\end{array}$ & $\begin{array}{c}\text { Average } \\
\text { age } \\
\text { (yr) }\end{array}$ & Wu & Wi & $\begin{array}{c}\text { Wu - } \\
\text { Wi }\end{array}$ & Zi & Zs & Zi - Zs & $\begin{array}{c}\text { Loss } \\
\left(\mathrm{m}^{3} \text { of }\right. \\
\text { wood) }\end{array}$ & $\begin{array}{c}\text { Loss } \\
(\mathrm{zl})\end{array}$ \\
\hline II a & $21-30$ & 25 & 742.2 & 348.0 & 394.2 & 1.00 & 0.97 & 0.03 & 11.8 & 1274 \\
\hline II b & $31-40$ & 35 & 742.2 & 456.5 & 285.7 & 1.00 & 0.87 & 0.13 & 37.1 & 4000 \\
\hline III a & $41-50$ & 45 & 742.2 & 544.1 & 198.1 & 1.00 & 0.85 & 0.15 & 29.7 & 3200 \\
\hline III b & $51-60$ & 55 & 742.2 & 611.0 & 131.2 & 1.00 & 0.83 & 0.17 & 22.3 & 2402 \\
\hline IV a & $61-70$ & 65 & 742.2 & 659.9 & 82.3 & 1.00 & 0.81 & 0.19 & 15.6 & 1684 \\
\hline IV b & $71-80$ & 75 & 742.2 & 694.7 & 47.5 & 1.00 & 0.78 & 0.22 & 10.5 & 1125 \\
\hline V a & $81-90$ & 85 & 742.2 & 719.0 & 23.2 & 1.00 & 0.75 & 0.25 & 5.8 & 625 \\
\hline V b & $91-100$ & 95 & 742.2 & 735.9 & 6.3 & 1.00 & 0.72 & 0.28 & 1.8 & 190 \\
\hline
\end{tabular}

loss borne and the rotation age adopted (there is a shorter period over which the costs incurred prior to the obtainment of income is prolonged, i.e. the stand rotation age achieved).

As the figures under discussion and appended tables make clear, the greatest losses were borne in stands of ages 30-40, in the LG habitat, where the rotation age exceeds 100 years - here the abandonment of prophylactic action might mean a loss of around $4600 \mathrm{PLN}$ ( 1 euro $\approx 4 \mathrm{PLN}$ ) per ha per year. Where stands are of rotation ages up to 100 years the value is smaller - up to 900 euro/ha/year. However, there 


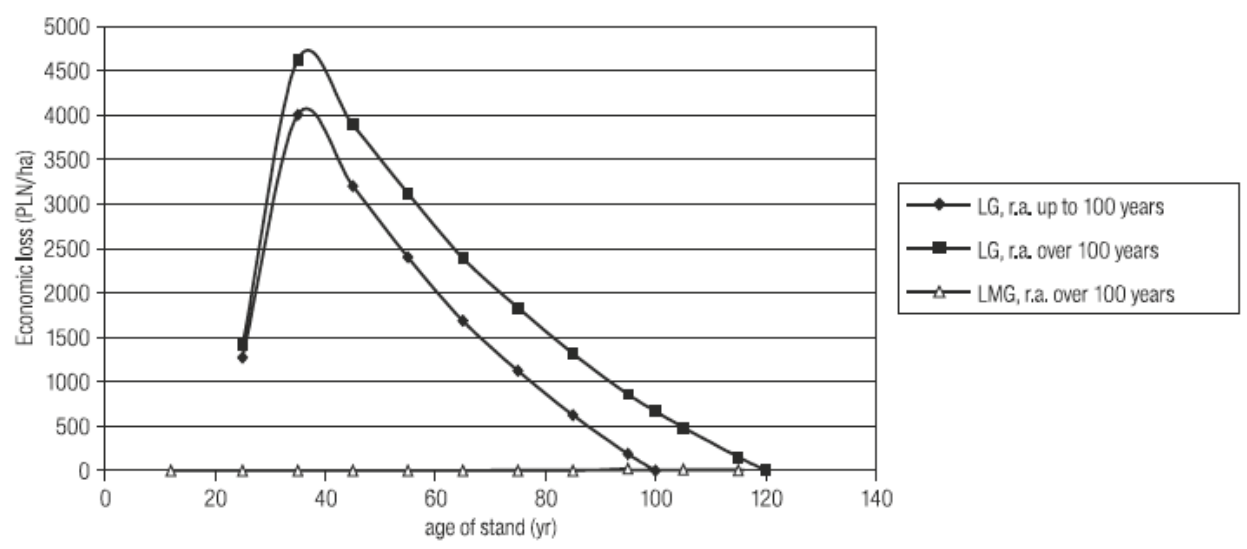

Fig. 8. Level of potential losses should the combating of Armillaria be abandoned in spruce stands of the LG and LMG habitats (r.a. - rotation age); 4 PLN $\approx 1$ euro.

is a minimal level of loss in the stands on the LMG habitat, to the point where this need not be taken into account. Any refraining from protective activity in stands of rotation age in excess of 100 years would incur losses of up to 5 euros per ha per year in stands over 100 years old.

\section{CONCLUSIONS}

On the basis of the above analysis, it is possible to state that:

- potentially major losses in the value of spruce stands colonised by Armillaria may arise in the LG habitat, though potential losses in the LMG are rather of marginal significance from the point of view of forestry management,

- the greatest economic losses may arise in stands 30-40 years old; with further increases in stand age, losses will tend to decline to the point where they are equal to zero by the time of felling,

- the level of less is thus influenced to a marked extent by the age at which the stand is cut - with greater losses characterizing stands with longer rotation period.

\section{REFERENCES}

Ca pecki Z. 1994. Rejony zdrowotności lasów zachodniej części Karpat. Prace Inst. Bad. Leśn. A 781: 61-125.

Capecki Z. 1997. Rejonizacja zdrowotności lasów środkowej części Karpat. Prace Inst. Bad. Leśn. A 840: 83-191.

Komunikat Prezesa Glównego Urzędu Statystycznego z dnia 20 października 2003 r. w sprawie średniej ceny sprzedaży drewna, obliczonej wedhug średniej ceny drewna uzyskanej przez nadleśnictwa za pierwsze trzy kwartaly 2003, M.P. Nr 50, poz. 787.

Le ch P. 2003. Zagrożenie drzewostanów świerkowych w Polsce przez patogeny korzeni w świetle wyników monitoringu fitopatologicznego lasów gospodarczych. (In:) A. Gr zyw ac z (ed.). Drzewostany świerkowe - stan, problemy, perspektywy rozwojowe. Materialy Sesji Naukowej PTL, UstrońJaszowiec: 92-107.

Łakomy P. 1998. Monitoring huby korzeni i opieńkowej zgnilizny korzeni w wybranych uprawach sosnowych Krainy Wielkopolsko-Pomorskiej. Roczniki Akademii Rolniczej w Poznaniu. Rozprawy Naukowe 283: 1-120. 
Łakomy P., Siwecki R. 2000. Gatunki z rodzaju Armillaria występujące w Nadleśnictwie Smolarz. Sylwan 4: 115-121.

Manion P.D. 1981. Tree disease concepts. Prentice Hall Inc., New Jersey.

Podgórski M., Beker C., Biczkowski Z., Najgrakowski T., Turski M. 2001. Podstawy wyceny lasów. Zachodnie Centrum Organizacji, Zielona Góra. 254 pp.

Rozporządzenie Ministra Środowiska z dnia 20 czerwca 2002 r. w sprawie jednorazowego odszkodowania za przedwczesny wyrąb drzewostanu, Dz.U. 2002 r. Nr 99, poz. 905.

Sierota Z., Le ch P. 1996. Monitoring fitopatologiczny w lasach gospodarczych. I. Założenia i zakres oceny. Sylwan 3: 5-16.

Sierota Z., Małecka M., Stocka T. 2003. Choroby infekcyjne. (In:): Krótkoterminowa prognoza występowania ważniejszych szkodników i chorób infekcyjnych drzew leśnych w Polsce w 2002 roku. Warszawa: 94-95.

Szabla K. 2003. Historia, problemy, uwarunkowania i perspektywy rozwojowe leśnictwa na terenie Regionalnej Dyrekcji Lasów Państwowych Katowice. (In:) A. Grzywacz (ed.). Drzewostany świerkowe - stan, problemy, perspektywy rozwojowe, PTL, Ustroń-Jaszowiec: 160-195.

Szymkiewicz B. 2001. Tablice zasobności i przyrostu drzewostanów ważniejszych gatunków drzew leśnych. Państwowe Wydawnictwo Rolnicze i Leśne. Warszawa.

Trample r T. 1990. Siedliskowe podstawy hodowli lasu. Dodatek do 5 wydania „Zasad hodowli lasu”. Państwowe Wydawnictwo Rolnicze i Leśne. Warszawa.

Tram pler T., Kliczkowsk a A., D myterk o E., Sier pińska A. 1990. Regionalizacja przyrodniczoleśna na podstawach ekologiczno-fitosocjologicznych. PWRiL, Warszawa.

Ustawa z dnia 3 lutego 1995 r. o ochronie gruntów rolnych i leśnych (z późniejszymi zmianami). Dz.U. 1995 r. Nr 16, poz. 78.

Zając S., Głowack a B., J abłoński T., Janeczko K., Jarosz K., Klocek A., Kolk A., Piekut in J., S to c k i J. 1998. Ocena ekonomiczna zwalczania szkodników w aspekcie zachowania trwałości lasów. Dokumentacja Instytutu Badawczego Leśnictwa. Warszawa.

Zwoliński J. 2003. Ocena zagrożenia lasów świerkowych w Beskidzie Śląskim przez zanieczyszczenia powietrza atmosferycznego. Prace Inst. Bad. Leśn. 1 (951): 53-68

Żółci a k A. 1991. Zmienność wewnątrz gatunkowa grzybów z rodzaju Armillaria - identyfikacja polskich izolatów z rodzaju Armillaria. Sylwan 11: 27-40.

Żółci a k A. 1999a. Identyfikacja gatunków grzybów z rodzaju Armillaria (Fr.:Fr.) Staude w Polsce. Prace Inst. Bad. Leśn. 888: 3-19.

Żółciak A. 1999b. Występowanie grzybów z rodzaju Armillaria (Fr.:Fr.) Staude w kompleksach leśnych w Polsce. Prace Inst. Bad. Leśn. A 890: 29-40.

Żółciak A. 2003. Rozmieszczenie grzybów z rodzaju Armillaria w Polsce oraz ich rośliny żywicielskie. Prace Inst. Bad. Leśn. A 956: 7-22.

\section{Występowanie i ekonomiczne straty powodowane przez grzyby z rodzaju Armillaria we Wschodnich Karpatach}

\section{Streszczenie}

Opieńkowa zgnilizna korzeni powodowana przez grzyby rodzaju Armillaria stanowi, obok huby korzeni, jeden z najbardziej istotnych problemów ochrony lasu. Największe straty ponoszone są przez jednostki alp w drzewostanach iglastych: według danych RDLP powierzchnia drzewostanów w Polsce, gdzie stwierdzono szkody spowodowane przez opieńki wyniosła w 1999 roku 144 tys. ha, a już w 2003 roku szacowano ją na ponad 200 tys. ha. Choroba występuje w drzewostanach wszystkich klasach wieku zarówno iglastych, jak i liściastych. Najbardziej zagrożone są drzewostany w regionach południowych kraju (RDLP Katowice i Wrocław), w Polsce północno-wschodniej (RDLP Olsztyn i Białystok) oraz w części północno-zachodniej (RDLP Szczecin i RDLP Toruń). W niektórych rejonach dochodzi do gwałtownego nasilenia wydzielania się posuszu świerkowego, przyjmującego $\mathrm{w}$ wielu wypadkach postać rozpadu drzewostanów. Dotyczy to w sposób szczególny obszaru Beskidu Śląskiego 
i Żywieckiego, gdzie w niżej położonych drzewostanach sytuacja jest katastrofalna. Wymuszone tempem zamierania drzew intensywne cięcia sanitarne skutkują postępującym przerzedzeniem drzewostanów, co zwiększa ich podatność na dalsze szkody powodowane przez czynniki abiotyczne (wiatr, śnieg) oraz biotyczne (patogeny, owady kambiofagiczne).

W pracy zaprezentowano i przedyskutowano wyniki badań dotyczące analizy ekonomicznej kosztów zabiegów ochronnych i ograniczania strat spowodowanych przez opieńkową zgniliznę korzeni, które mogą dochodzić nawet do 1000 euro z ha. Analiza ekonomiczna kosztów związanych z ograniczaniem rozwoju patogenicznych opieniek w drzewostanach uszkodzonych i zagrożonych dostarcza informacji niezbędnych do podejmowania decyzji o konieczności wykonywania zabiegów lub ich zaniechania. Pozwolą one na opracowanie strategii polityki ochrony na różnych szczeblach decyzyjnych oraz będą pomocne przy podejmowaniu decyzji odnośnie pilności przebudowy drzewostanów (dostosowania składu gatunkowego do siedliska) lub minimalizacji szkód w nadleśnictwach o dużym zagrożeniu (np. Ujsoły, Ustroń, Wisła). 